Jurnal Pena Sains Vol. 5, No. 2, Oktober 2018

p-ISSN: 2407-2311

e-ISSN: 2527-7634

\title{
REVIEW $\pi$ : WHAT IS THE DESCRIPTION OF STUDENTS' INTEREST IN PHYSICS?
}

\author{
Agus Budiyono $^{1}$ dan Linda Tri Antika ${ }^{2}$ \\ ${ }^{1}$ Pendidikan Fisika, FKIP, Universitas Islam Madura Pamekasan, 69351, Indonesia \\ abybudiyono@gmail.com \\ ${ }^{2}$ Pendidikan Biologi, FKIP, Universitas Islam Madura Pamekasan, 69351, Indonesia \\ lindatriantika@gmail.com
}

Accepted: Sept 27, 2018 Published: October 31, 2018

\begin{abstract}
This study was based on the potential of new methods in knowing students' interest in physics lessons. Interest in learning physics was the tendency and interest of students to learn process and try to know and understand the material physics with experience of the environment both content and contextual. The subject of physics was more emphasis on the count, and then in each calculation equation was made in the form of symbols. Symbols that are often used in physics are the Greek alphabet. One of the most commonly used was the symbol " $\pi$ ". It was a Greek alphabet pronounced with pi. It was commonly used on exact subjects. The value " $\pi$ " was 3.14 or 22/7 otherwise the value " $\pi$ " was $180^{\circ}$. The use of " $\pi$ " symbol in the level of education unit of High School as much as 10 material of physics.
\end{abstract}

Keywords: $\pi$, interest and Physics' 


\section{Introduction}

The focus of recent physics education research has led to how physics learning can increase students' interest in physics. Search interests and efforts to increase students' interest in physics using the application of models, strategies and learning methods. Ateş and Eryilmaz (2011), Erdemir (2009), Seven, et al (2011), Selcuk (2010), using the application of a model in an effort to increase student achievement and interest to physics. Furthermore Supriadi, et al (2011) and Yulianto, et al (2010) also use a learning model in an effort to increase students' interest in physics.

In its development after the model, strategy and method of learning has been implemented, a method or method is needed so that interest continues and the measurement of student interest continues. So that without the application of a model, strategy and learning method can be measured regarding the description of students' interest in physics. The existence of a potential new method in identifying students 'interest in physics is one of them is by knowing students' understanding of the symbol $\pi$.

The symbol $\pi$ is very closely related to the exact lesson because in exact lessons such as mathematics and physics usually use the symbol $\pi$. The symbol $\pi$ was first used by William Jones in 1706. Furthermore, the use of the bol $\operatorname{sim} \pi$ widely until now popularized by mathematician Leonhart Euler.

In this study the author uses the search for student interest in physics lessons by the method $\pi$. This is done because physics lessons when compared to other science lessons use more calculation of numbers, so that students assume that physics lessons are a difficult and frightening lesson. In physics subjects that emphasize more on the count, in each calculation symbols are made and one that is often used is the symbol $\pi$.

The $\pi$ symbol used in physics material at the high school unit level is 10 physical materials according to the equation in each material. Physics subjects in high school are presented in five lesson hours (5 x 45 minutes) each week, so students in high school often intersect with the main Greek alphabet symbols Symbol $\pi$.

This $\pi$ symbol that is commonly used will have an impact on the easy to remember by students, so that the mention, writing and the value of $\pi$ are also used to be used and remembered by students. For that, it is easy to remember this indicates how far students' interest in physics subjects. For this reason, it is very interesting to study the extent to which students understand the symbol $\pi$ which indicates that students are interested in physics.

\section{Research Method}

This paper is a study obtained based on literature studies and author experience in the Tri Dharma College activities. School physics teaching experience and the results of observations and interviews and research for students in Pamekasan District High School. The library deals with the symbol $\pi$ in school physics subjects as well as the literature that deals with tracing students 'interest in physics, so a new way is needed in tracing the picture of students' interest in physics.

Based on the results of school physics lectures and observations and interviews regarding this interest search will discussed further in this paper. Literature and the results - the results of research is still being done to get more study comprehensive 


\section{Review $\pi$ : What is the description of students' interest in physics?}

\section{Results and Discussion}

Physics subjects are one of the subjects in the science / science family which are closely related to everyday life. Collette and Chiappetta in (Sutrisno, 2006 ) state that "science is essentially a collection of knowledge (" a body of knowledge "), a way or way of thinking (" a way of thinking "), and a way of inquiry (" a way of investigating ")". Another term that is also used to express the nature of science is science as a product to substitute an IPA statement as a collection of knowledge (" a body of knowledge "), IPA as an attitude to substitute an IPA statement as a way of thinking, and IPA as a process for replacing the IPA statement as a way of investigation (" a way of investigating "). Because physics is part of science or science, we can equate the perception that the nature of physics is the same as the nature of science or science, the nature of physics is a product (" a body of knowledge "), physics as an attitude (" a way of thinking "), and physics as a process (" a way of investigating ").

Physics as a product means that the physics of knowledge can be in the form of facts, concepts, principles, laws, formulas, theories and models. Furthermore, physics as a process means that physics provides a description of how scientists work on discoveries, so science as a process of giving a description of the approach used to compile the latest knowledge or terms in physics learning is that students have science process skills consisting of 1) Observing , 2) Classifying, 3) Measuring, 4) Asking questions, 5) Formulating hypotheses, 6) Planning Investigations, 7) Interpreting, 8) Communicating and 9) Asking questions (Ostlund, 1992).

Furthermore physics as an attitude means in teaching physics should adopt the thoughts of scientists engaged in physics who have a great attitude of curiosity and curiosity, accompanied by trust, objective attitude, honest and open and willing to listen to people's opinions other.

At the level of senior high school (SMA) based on Permendikbud (2016) the physics courses are taught as many as five lesson hours ( $5 \times 45$ minutes $)$, see standard process meaning material cultivation about physics is very ideal and indicates physics can be learned and even sought by students. For this reason, students have embedded the soul of physics, which consists of three essentials of learning physics.

Viewed from the understanding of Etymology, interest means attention, preference (tendency) of the heart for an activity (Poerwodarminto, 1984). Whereas according to meaning Terminology of interest means a continuous desire to pay attention or do something. Interest can generate enthusiasm in carrying out activities so that the objectives of these activities can be achieved. And the spirit that exists is the main capital for each individual to carry out an activity (Ministry of Education and Culture, 1997). In line with that according to Yulianto (2010) someone who are interested in a lesson will tend earnest in learning the lesson the opposite, someone who is less interested towards a lesson will tend to be reluctant learn the lesson. From the definition above, it can be concluded that interest is the tendency of a person to like, to have a continuous desire for an object, so as to generate enthusiasm for activities so that the desired goal can be achieved.

While learning is a business process carried out by a person to obtain a change in new behavior as a whole, as a result of his own experience in interaction with his environment (Slameto, 2013) . Whereas 


\section{Budiyono and Antika}

physics is a subject that is taken by students at the high school level at the specialization of science, which is taught five times a week ( $5 \times 45$ minutes).

So, interest in physics is the tendency and desire of students to learn process and try to know and understand physics material by way of experience in the environment both content and contextual. Asking for physics can be described by the great desire of a student to study and solve physics problems in everyday life.

Students' interest in physics can be improved and pursued through a learning model or method. Yulianto (2010) uses the Jigsaw Puzzle Competition learning model in Contextual Learning to increase students' interest in physics, further Ateş and Eryilmaz (2011) uses the hands on and minds on method in an effort to increase students' interest in physics. However, at this time there is no trace in determining students 'interest in physics through other methods, especially in correlating students' understanding of $\pi$.

Symbol $\pi$ in Physics Lessons and Interests towards Symbols $\pi$

The symbol $\pi$ was first used by William Jones in 1706. Furthermore, the use of the symbol $\pi$ extensively until now was popularized by mathematician Leonhart Euler (Sumardyono, without years). Symbol $\pi$, this is often used in physics lessons. The use of the symbol $\pi$ in physics subjects in high school is detailed as follows (Nugraha \& Sulaiman, 2013; Giancoli, 1988; Farchani, et al, 2016):

1. Circular motion with the equation $\mathrm{v}=$ $2 \pi \mathrm{f} \mathrm{R}$

2. In angular momentum there is a unit of magnitude of $2 \pi$ radians.

3. Stoke Law with the equation $\mathfrak{f}=\pi \mu \mathrm{r}$ $\mathrm{V}$
4. Deviation of harmonic motion with equations $y=A \sin \left(\frac{2 \pi}{T}\right)+\theta$

5. Frequency and vibration period with equations $T=2 \pi \sqrt{ } \frac{l}{g}$

6. The force acting on the vibration of harmony $\mathrm{k}$ with the equation $T=$ $2 \pi \sqrt{ } \frac{m}{k}$

7. The equation of the current wave deviation is $y=A \sin 2 \pi f\left(t \pm \frac{x}{v}\right)$

8. Wave intensity with equation $I=2 \rho v$ $\pi^{2} f^{2} A^{2}$

9. Magnetic induction around electrically powered wires with similarities $B=\frac{\mu 0}{2 \pi} \frac{1}{a}$

10.Inductive reactance $X \mathrm{~L}$ with the equation $X_{L}=2 \pi f . L$

Interest in the symbol $\pi$ can be defined as a tendency and desire of students to learn, process, and seek to know and understand about the symbol $\pi$, so that when students are faced with the symbol $\pi$ then students do not find it difficult in solving mathematical problems since the symbol $\pi$ is already very familiar in themselves students as well as the symbol $\pi$ own mind to the optimum by students both mention, writing up the value of the symbol $\pi$. The tendency of students to like symbols this has an impact on the ease of students in solving mathematical problems in physics, when students meet with mathematical equations in which there is a symbol $\pi$, and then students will be interested in completing the equation.

From the amount of material that uses the symbol $\pi$ this reinforces that $\pi$ does not feel alien to students. Furthermore the value of $\pi$ even in physics lessons there are two values, namely 3.14 or and also worth $180^{\circ}$ that is in units of rotation value of 2 radians $=$ $360^{\circ}$. It means in two variations of values 
Review $\pi$ : What is the description of students' interest in physics?

symbol $\pi$ with different values this gives a special impact and interest for students who eventually pay more attention to and remember symbols $\pi$ and the value. This method $\pi$ will be effective in determining and tracing students' interest in physics lessons. Thus this understanding is very likely correlated with student interest in physics, with a high understanding of $\pi$ then become the base like a physics lesson.

\section{Conclusion}

Based on the results of the literature review, it can be drawn to the conclusion that: 1. Physics lessons are identical to lessons that present symbols and numbers; 2. Symbol in high school physics lessons are presented in 10 subtopics of discussion; and 3. Understanding of students on can be correlated with students' interest in physics.

\section{References}

Ateş, Ö dan Eryilmaz, A. (2011). Effectiveness of hands-on and minds-on activities on students' achievement and attitudes towards physics. Asia-Pacific Forum on Science Learning and Teaching, 12 (1), Article 6.

Depdikbud. (1997). Pembinaan Minat Baca, Materi Sajian. Jakarta: Dirjen Dikdasmen Depdikbud RI.

Erdemir .2009. Determining Students' Attitude Towards Physics Through Problem-Solving Strategy. Asia-Pacific Forum on Science Learning and Teaching, 10 (2). Article 1

Farchani, M. (2016). Kajian Konsep Fisika 1. Solo: PT. Tiga Serangkai Pustaka Mandiri.
Giancoli, D. (1998). Fisika Edisi Kelima. PT. Gelora Aksara Pratama.

Kemendikbud. (2016) Permendikbud Nomor 22 Tahun 2016 tentang Standar Proses Pendidikan Dasar dan Menengah. Jakarta: Kemendikbud.

Nugraha, S dan Sulaiman. (2013). Rumus Sakti Fisika SMA/MA. Jakarta Timur: Dunia Cerdas.

Ostlund, K. L. (1992). Science Process Skills Assessing Hands-on Student Performance. America: Addison.

Poerwodarminto (1984). Kamus Umum Bahasa Indonesia. Jakart: Balai Pustaka.

Selcuk, G. 2010. The effects of problembased learning on pre-service teachers' achievement, approaches and attitudes towards learning physics. International Journal of the Physical Sciences. 5 (6), hlm. 711-723.

Seven, S, dkk .2011. Effects of Guide Materials Based on 5E Model on Students' Conceptual Change and Their Attitudes towards Physics: A Case for 'Work, power and Energy' Unit. Turkish Science Education, 8 (1), hlm. 139-152.

Slameto. (2013). Belajar dan Faktorfaktor Yang Mempengaruhinya. Jakarta: Rineka Cipta Cetakan ke 6.

Sumardyono (Tanpa tahun). Sejarah Penggunaan Simbol Konstanta $\pi$. Makalah 


\section{Budiyono and Antika}

Supriadi, dkk. 2011. Penerapan Physics Communication Games dengan Pendekatan SETS untuk Meningkatkan Pemahaman Kebencanaan dan Minat Belajar Sains Fisika Siswa SMP. Jurnal Pendidikan Fisika Indonesia 7 (2011), hlm 101-105.

Sutrisno, 2006. Fisika Dan Pembelajarannya. Bandung: FPMIPA UPI. Makalah

Yalçin, S. 2009. The Effect of Project Based Learning on Science Undergraduates' Learning of Electricity, Attitude towards Physics and Scientific Process Skills. International Online Journal of Educational Sciences. 1 (1), hlm. 81-105.

Yulianto, A, dkk (2010). Penerapan Jigsaw Puzzle Competition dalam Pembelajaran Kontekstual untuk Meningkatkan Minat dan Hasil Belajar Fisika Siswa SMP. Jurnal Pendidikan Fisika Indonesia 6 (2010), hlm. 84-89.. 